\title{
Progesterone secretion during pregnancy and pseudopregnancy in the ferret
}

\author{
Francesca R. Blatchley and B. T. Donovan \\ Department of Physiology, Institute of Psychiatry, \\ De Crespigny Park, London SE5 8 AF, U.K.
}

In the ferret, pregnancy and pseudopregnancy last 6 weeks. Histological study of the CL and endometrium indicates a parallel rate of progestin secretion in the two conditions (Deanesly, 1967) and suggests that the products of conception do not affect $C L$ activity in this species. Further evidence has been sought on this point by assay of the progesterone content of plasma samples collected from pregnant and pseudopregnant ferrets. In the present work, pseudopregnancy was induced by mating so that comparison could be made with the progesterone levels in females rendered pseudopregnant by injection of LH (Blatchley \& Donovan, 1972). After this work was completed the results of a similar study were published by Heap \& Hammond (1974).

Ferrets of the albino and polecat varieties were used. They were kept under a lighting regimen of $16 \mathrm{hr}$ light: $8 \mathrm{hr}$ dark and fed a proprietary diet with water freely available. Animals were inspected at weekly intervals for vulval swelling and when fully in oestrus were paired with a fertile or a vasectomized male for $24 \mathrm{hr}$ or injected s.c. with $300 \mu \mathrm{g} \mathrm{LH}$ (NIH-LH-B4). The day of mating or gonadotrophin injection was designated Day 0. On Days 1-5, Day 7 and at weekly intervals thereafter, 2 $\mathrm{ml}$ blood were collected by cardiac puncture into heparinized syringes under pentobarbitone sodium (Nembutal: Abbott Laboratories) anaesthesia, and the plasma stored at $-20^{\circ} \mathrm{C}$ until assay. Some mated females were autopsied on or around Day 42, so that the state of the uteri and the number of fetuses (if any) could be noted. The ovaries and uteri were fixed in formol saline for subsequent histological examination. Pseudopregnant ferrets were those animals which had been mated with vasectomized males together with those in which normal mating proved infertile.

Progesterone was measured in duplicate $50 \mu \mathrm{l}$ plasma samples by the radioimmunoassay method of Furr (1973). The antiserum, raised in goats against progesterone-1 $1 \alpha$-succinyl-bovine serum albumin, was used at a dilution of $1: 10,000$. The mean ( \pm S.E.M.) percentage extraction of $\left[{ }^{3} \mathrm{H}\right]$ progesterone added to plasma samples was $90 \pm 0 \cdot 8 \%$ (range $82-95 \%$ ). The sensitivity, defined as the least amount of unlabelled progesterone causing a significant displacement of labelled progesterone from the antibody- $\left[{ }^{3} \mathrm{H}\right]$ progesterone complex, was $30 \mathrm{pg}$, and the coefficient of variation of duplicate samples over the range of the assay above $30 \mathrm{pg}$ was $<10 \%$. Progesterone levels in some plasma samples from pregnant ferrets and in those from animals in which pseudopregnancy was hormonallyinduced were measured by a competitive protein-binding assay (Blatchley, Donovan, Horton \& Poyser, 1972). Comparison of values obtained by either method showed that the assays were comparable at levels above $1 \mathrm{ng} / \mathrm{ml}$. The mean values obtained from the various groups were compared by Student's $t$ test for independent data.

The progesterone levels are shown in Table 1. In the LH-treated ferrets progesterone levels rose steadily from the day after the injection to a maximum on Day 21 and steadily declined thereafter. No appreciable change in luteal structure or size occurred while hormone levels fell. The pattern of progesterone secretion in the mated pseudopregnant animals was similar; maximal levels were recorded on Day 14 and declined after Day 21. Changes in CL histology were also similar. In pregnant ferrets progesterone levels on Day 7 were slightly, but not significantly, higher than those in pseudopregnant animals. Maximal values were again reached by Day 14 and a steady fall occurred after Day 21. A normal complement of $\mathrm{CL}$ had been formed and these were still large and appeared healthy on Day 42, as in the other two groups.

These findings, and those of Carlson \& Rust (1969) and Heap \& Hammond (1974), indicate that the placenta does not secrete progesterone in sufficient quantity to raise the blood level of the 
Table 1. The mean ( \pm S.E.M.) plasma concentration of progesterone ( $\mathrm{ng} / \mathrm{ml})$ during pregnancy and pseudopregnancy in the ferret (nos of observations in parentheses)

\begin{tabular}{|c|c|c|c|c|c|c|c|}
\hline \multirow[b]{2}{*}{ Day } & \multicolumn{2}{|c|}{ Pseudopregnancy } & \multirow[b]{2}{*}{ Pregnancy } & \multirow[b]{2}{*}{ Day } & \multicolumn{2}{|c|}{ Pseudopregnancy } & \multirow[b]{2}{*}{ Pregnancy } \\
\hline & LH-induced & Male-induced & & & LH-induced ${ }^{*}$ & Male-induced & \\
\hline 1 & $1.47 \underset{\text { (4) }}{ \pm 0} 0.60$ & $0.70,0.70$ & - & 14 & ${ }_{(6)}^{15 \cdot 76 \pm 3 \cdot 52}$ & $\begin{array}{c}16 \cdot 36 \pm 1 \cdot 53 \\
(28)\end{array}$ & ${ }_{(16)}^{16 \cdot 12 \pm 2 \cdot 28}$ \\
\hline 2 & $1.96 \pm 0.18$ & 一 & 一 & 21 & $\begin{array}{c}17 \cdot 7 \pm 2 \cdot 10 \\
(7)\end{array}$ & $\begin{array}{c}14 \cdot 86 \pm 1 \cdot 71 \\
(29)\end{array}$ & $\begin{array}{c}13 \cdot 24 \pm 1 \cdot 90 \\
(17)\end{array}$ \\
\hline 3 & $\frac{2 \cdot 30 \pm 0.42}{(3)}$ & $1 \cdot 5,5 \cdot 0$ & - & 28 & $\frac{10 \cdot 22 \pm 2 \cdot 34}{(6)}$ & $\begin{array}{c}10 \cdot 38 \pm 1 \cdot 04 \\
(29)\end{array}$ & $\begin{array}{c}10 \cdot 20 \pm 1 \cdot 47 \\
(16)\end{array}$ \\
\hline 4 & $4 \cdot 10,4 \cdot 10$ & - & - & 35 & $\frac{3.78 \pm 0.55}{(5)}$ & $\underset{(27)}{6.18 \pm 0.71}$ & $\begin{array}{c}4 \cdot 76 \pm 1 \cdot 19 \\
(16)\end{array}$ \\
\hline 5 & $6 \cdot 47 \pm 1 \cdot 18$ & $5 \cdot 0,6 \cdot 5$ & - & 42 & $2 \cdot 72 \pm 0.43$ & $4.80 \pm 0.62$ & $2.84 \underset{(5)}{ \pm 0.68}$ \\
\hline 7 & $\begin{array}{c}7.81 \pm 0.73 \\
\text { (9) }\end{array}$ & $\begin{array}{c}8.98 \pm 0.98 \\
(28)\end{array}$ & $\begin{array}{c}12 \cdot 82 \pm 2 \cdot 06 \\
(13)\end{array}$ & & & & \\
\hline
\end{tabular}

* Data from Blatchley \& Donovan (1972).

hormone in the pregnant ferret above that found in the pseudopregnant female. Further, the similar degree of progesterone secretion in pregnancy and pseudopregnancy substantiates the view that the hypophysis, and not the placenta, is the major source of luteotrophin in this species (McPhail, 1935; Donovan, 1963; Galil, 1965).

With the decline in progesterone secretion evident in the pregnant female from Day 21 , it is remarkable that birth so consistently occurred on Day 42 . The nature of the timing mechanism remains unknown, but it is also interesting that structural luteolysis does not appear to occur until functional luteolysis is virtually complete.

We thank the Population Council, New York, for financial support, Dr B. J. A. Furr for the gift of the progesterone antibody, NIAMDD for the LH, and Maureen Harrison for excellent technical assistance.

\section{References}

Blatchley, F.R. \& Donovan, B.T. (1972) Peripheral plasma progestin levels during anoestrus, oestrus and pseudopregnancy and following hypophysectomy in ferrets. J. Reprod. Fert. 31, 331-333.

Blatchley, F.R., Donovan, B.T., Horton, E.W. \& POYSER, N.L. (1972) The release of prostaglandins and progestin into the utero-ovarian venous blood of guinea-pigs during the oestrous cycle and following oestrogen treatment. J. Physiol., Lond. 223, $69 \rightarrow 88$.

Carlson, I.H. \& Rust, C.C. (1969) Plasma progesterone levels in pregnant, pseudopregnant and anestrous ferrets. Endocrinology 85, 623-624.

DEANESLY, R. (1967) Experimental observations on the ferret corpus luteum of pregnancy. $J$. Reprod. Fert. 13, 183-185.
Donovan, B.T. (1963) The effect of pituitary stalk section on luteal function in the ferret. J. Endocr. 27, 201-211.

FURR, B.J.A. (1973) Radioimmunoassay of progesterone in peripheral plasma of the domestic fowl in various physiological states and in follicular venous plasma. Acta endocr., Copenh. 72, 89-100.

GALIL, A.K.A. (1965) Utero-ovarian interrelationships during gestation: endocrine role of the placenta. Ph.D. thesis, London University.

HeAP, R.B. \& Hammond, J., JR (1974) Plasma progesterone levels in pregnant and pseudopregnant ferrets. J. Reprod. Fert. 39, 149-152.

McPhaIL, M.K. (1935) Studies on the hypophysectomized ferret. IX. The effect of hypophysectomy on pregnancy and lactation. Proc. $R$. Soc. B 117, 34-45. 